\title{
Adaptation Selection of Plants for Utilization in Phytoremediation of Soil Contaminated by Crude Oil
}

\author{
Fadliah Salim ${ }^{1}$, Yadi Setiadi ${ }^{1}$, Didy Sopandie ${ }^{2}$, Mohamad Yani ${ }^{*}$ \\ ${ }^{1}$ Department of Silviculture, Faculty of Forestry, IPB University, Bogor, Indonesia \\ ${ }^{2}$ Department of Agronomy and Horticulture, Faculty of Agricultural, IPB University, Bogor, Indonesia \\ ${ }^{3}$ Department of Agroindustrial Technology, Faculty of Agricultural Engineering and Technology, IPB University, Bogor, Indonesia
}

\section{ARTICLE INFO}

Article history:

Received January 1, 2018

Received in revised form October 17, 2019

Accepted October 25, 2019

\section{KEYWORDS:}

adaptation selection,

crude oil,

morphological and anatomical responses, phytoremediation,

total petroleum hydrocarbon,

\begin{abstract}
The research on adaptation selection for utilization in phytoremediation of soil contaminated by crude oil using four type plants, such as Helianthus annuus, Paspalum conjugatum, Sorghum bicolor, and Tagetes erecta were conducted. The adaptability of four types of plants on crude oil contaminated soil at total petroleum hydrocarbon (TPH) level at 0,3 , and $6 \%$ were observed and evaluated to their morphological and anatomical responses. Parameters observed were vegetative growth of plants including growth precentage, plant height, number of leaves, root length, root dry weight, shoot dry weight, root/shoot ratio, total dry weight, and stomatal density for 9 weeks cultivation in screen house. The results show that increasing in TPH level caused in significant reductions on morphological of four plants, such as percentage of plant growth, plant height, number of leaves, root length, root dry weight, shoot dry weight, and total dry weight. In contrast, the increasing in TPH level caused to increasing in root/shoot ratio. The four types of plants studied were effective to be used as plants for phytoremediation of petroleum contaminated soil. The plants of $P$. conjugatum and $S$. bicolor are recommended as phytoremediators for further studies.
\end{abstract}

\section{Introduction}

Mining companies that have locations in forest areas are obliged to reforest the area (Kemenhut 2011). Reforestation of petroleum contaminated soil can not be directly planted by tree species. Planting in forest areas can not be directly planted if the total petroleum hydrocarbon $(\mathrm{TPH})>3 \%$, because it can cause plant death at seedling level (Setiadi 2012). Petroleum is a source of energy that has many benefits, but if wasted into the environment, would be a hazardous waste. Petroleum contamination can occur due to spills or discharges during oil mining activities, such as exploration, exploitation, processing, and transportation (Singh and Jain 2003; Eapen and D'Souza 2005).

Environmental pollution caused by oil spills may cause ecosystems in the environment to be disturbed. Hydrocarbon spills to soil and water can poison the flora and fauna that live around contaminated soil,

\footnotetext{
* Corresponding Author

E-mail Address: moh.yani@apps.ipb.ac.id
}

including into the human body (Escalante-Espinosa et al. 2005; Merkl et al. 2005). Therefore, the action to overcome petroleum contaminated soil needs to be done so that pollution is not widespread.

There are three ways that can be carried out to overcome the oil spill, i.e. physically, chemically, and biologically. Physical handling is only able to cope with oil on the surface only, while chemical technique has side effects because it can cause new pollution. Nowadays, biological engineering is usually accomplished through bioremediation technique (Biswas et al. 2015). The bioremediation technique using plants is called phytoremediation. Phytoremediation uses certain plants and works with microorganisms to convert pollutants to be less harmful. It is a low-cost and environmentally friendly technique to reduce contaminated soils (Pilon-Smits 2005). Phytoremediation technology is usually used in conjunction with bioremediation methods for remediating contaminated soil as a polishing step, so that polluted areas can be recovered if they meet the quality standard (Yani et al. 2003). 
Little research in Indonesia was done to investigate potential plants for hydrocarbon phytoremediation. Not all plants will be adaptive to petroleum contamination. Studies on phytoremediation have shown that plants could help degrade petroleum hydrocarbon in soil, especially in the rhyzosphere (Macek et al. 2000; Gerhardt et al. 2009; Peng et al. 2009; Glick 2010). April and Sims (1990) also reported that a variety of plants have been known to have the potential to be used for phytoremediation. In contrast, some plant species could not reduce petroleum hydrocarbon in soil (Lalande et al. 2003; Euliss et al. 2008). Grasses and legumes have been used by researchers for phytoremediation studies (Merkl et al. 2005; Kaimi et al. 2006; Kirkpatrick et al. 2006).

Phytoremediation is a function of the root, so the plants used must have a strong root system and good root spreading (Setiadi et al. 1992). The selection of plant species that can be utilized for phytoremediation of a contaminants is a very important stage. According to Jones et al. (2004), the quality of rhizodeposition (the factor that drives the presence of microbes to the rhizosphere) depends on the type of plants. The purpose of this study was to obtain several types of plants which could adapt to petroleum contaminated soil by evaluating the decrease of TPH based on their morphological and anatomical responses to some concentrations of petroleum hydrocarbons.

\section{Materials and Methods}

\subsection{Location of Study}

The research was conducted at the Forest Biotechnology Laboratory-Biotechnology Resource Research Center-IPB University for plant adaptation preparation and plant morphological measurement. Stomatal measurement and root cross section were done at the Microtechnique Laboratory-Department of Agronomy and Horticulture-Faculty of Agriculture-IPB University. TPH analysis was carried out at the Analytical Laboratory-The Institute of Environmental TechnologyBadan Pengkajian dan Penerapan Teknologi (BPPT). Finally, conducting plant cultivation was acomplished at the screen house of Silviculture Department of Faculty of Forestry-IPB University.

\subsection{Materials}

The materials used were the seeds of four types of plants, i.e. Helianthus annuus, Paspalum conjugatum, Sorghum bicolor, and Tagetes erecta. Planting media used for plant adaptation experiment was the soil collected from a depth of 0-30 cm from Serpong area, Banten Province, Indonesia, and compost. Crude oil given to the soil was derived from community crude oil wells in Bojonegoro area, East Java, Indonesia.

\subsection{Research Procedure \\ 2.3.1. Plant Adaptation Preparation}

The soil used was sieved through a $2 \mathrm{~mm}$ screen. Soil as a growing medium (90\%) was mixed with compost (10\%), then poured crude oil at 0,3 , and $6 \% \mathrm{TPH}$. The contaminated soil were stirred manually, so that the soil was conditioned to have TPH-0, TPH-3, and TPH-6. The soil mixture was filled into plastic trays ( $31 \times 3.5$ x $23.5 \mathrm{~cm}^{3}$ and $34 \times 5 \times 26.5 \mathrm{~cm}^{3}$ ). Each experimental unit used $1.65 \mathrm{~kg}$ of mixed soil per tray.

S. bicolor seeds were first surface sterilized for 5 minutes in $5(\mathrm{v} / \mathrm{v})$ commercial $\mathrm{NaOCl}$, then washed in running tap water and soaked with water for 30 minutes. Seeds of $P$. conjugatum were first seeded directly in the tray filled with sands for about 10 days. The seeds of $H$. annuus and T. erecta were grown in the tray that have been filled with planting medium. All plants were grown with a spacing of $5 \times 5 \mathrm{~cm}^{2}$.

The plants were cultivated in the screen house. A total of 72 plastic trays were maintained in the screen house ( 36 trays for 4 types of plants, 3 replication, $3 \mathrm{TPH}$ concentrations and 36 trays for no plant treatments). The average temperature in the screen house was $27.1-31.9^{\circ} \mathrm{C}$ from minimum $24.9^{\circ} \mathrm{C}$ to maximum $44.1^{\circ} \mathrm{C}$. The average relative humidity was $45.7-52.9 \%$ from minimum $29 \%$ to maximum $82 \%$. Death plants was replaced within 7 days. Soil samples were taken before planting and after planting for TPH analysis. The same treatments were conducted in 36 trays for no plant treatments.

\subsubsection{Data Measurement and Laboratory Analysis 2.3.2.1. Morphological and Anatomical Responses}

There were three stages of harvesting: 3,6 , and 9 weeks. In each harvest, the variables measured were the precentage of plant growth (\%), plant height $(\mathrm{cm})$, number of leaves, root length $(\mathrm{cm})$, root dry weight $(\mathrm{g})$, shoot dry weight (g), root/shoot ratio, total dry weight (g), stomatal density (stomata $/ \mathrm{mm}^{2}$ ), and cross section of roots. Roots were separated from shoots and rinsed. Both shoots and roots were dried at $65^{\circ} \mathrm{C}$ for several days and weighed. Number of stomata measurement was performed under the Olympus CX 23 binocular microscope. Stomatal density is the number of stomata divided by the wide field of view. Cross section of roots was conducted by cutting the roots about $1 \mathrm{~cm}$ long, then placed on a glass object, put enough water to keep the sample from drying out, and placed the sample on Carton SCW-E binocular fixed magnification microscope. The fresh samples were cut as thin as possible using a razor, then it observed under the microscope. 


\subsubsection{Total Petroleum Hydrocarbon (TPH) Measurement}

TPH was measured gravimetrically using Method 3540C (Soxhlet Extraction, part of Test Methods for Evaluating Solid Waste) by US EPA (1996). Each treatment had 3 replications.

\subsubsection{Experimental Design and Data Analysis}

This research was conducted with Completely Randomized Design. The data were analyzed using analysis of variance (ANOVA) and Duncan Multiple Range (Gomez and Gomez 1984). Data processing was done using Statistical Analysis System (SAS) program 9.4. Each plant used was a separate research unit.

\section{Results}

\subsection{PlantMorphological andAnatomical Responses}

Treatments with 3 levels of TPH was resulted in significant reductions of the four plants morphologically after 9 week planting (Table 1 ). The plant morphological observed by the percentage of plant growth (\%), plant height $(\mathrm{cm})$, number of leaves, root length $(\mathrm{cm})$, root dry weight $(\mathrm{g})$, shoot dry weight $(\mathrm{g})$, root/shoot ratio, and total dry weight (g).

Figure 1 shows the growth percentage of the four plants selected with 3 levels of TPH treatment after 3,6 , and 9 weeks of planting. The highest growth percentage was achieved by $P$. conjugatum (100\%)

Table 1. The growth performance of plant height, root length, root dry weight, shoot dry weight, root/shoot ratio, total dry weight, and stomatal density of $H$. annuus, P. conjugatum, S. bicolor, and T. erecta at 3 level of TPH $(0,3,6 \%)$ after 9 weeks planting

\begin{tabular}{|c|c|c|c|c|}
\hline Parameter and TPH level & H. annuus & P. conjugatum & S. bicolor & T. erecta \\
\hline \multicolumn{5}{|l|}{ Plant height (cm) } \\
\hline TPH-0 & $27.76 \pm 9.42 \mathrm{~A}$ & $14.60 \pm 4.62 \mathrm{~A}$ & $14.20 \pm 3.75 \mathrm{~A}$ & $17.06 \pm 4.71 \mathrm{~A}$ \\
\hline ТPH-3 & $15.62 \pm 4.45 \mathrm{AB}$ & $7.26 \pm 0.96 \mathrm{~B}$ & $9.43 \pm 0.23$ B & $5.37 \pm 1.07$ B \\
\hline TPH-6 & $8.83 \pm 2.46 \mathrm{~B}$ & $2.41 \pm 0.79 \mathrm{~B}$ & $5.07 \pm 1.10 \mathrm{~B}$ & $2.47 \pm 0.87 \mathrm{~B}$ \\
\hline \multicolumn{5}{|l|}{ Leaf number } \\
\hline TPH-0 & $11.00 \pm 4.85 \mathrm{~A}$ & $15.73 \pm 1.72 \mathrm{~A}$ & $5.00 \pm 0.69 \mathrm{~A}$ & $17.26 \pm 1.81 \mathrm{~A}$ \\
\hline ТРН-3 & $6.40 \pm 3.48 \mathrm{~A}$ & $5.93 \pm 0.41 \mathrm{~B}$ & $5.67 \pm 0.30 \mathrm{AB}$ & $10.13 \pm 0.80$ B \\
\hline ТPH-6 & $4.27 \pm 3.71 \mathrm{~A}$ & $5.27 \pm 1.22 \mathrm{~B}$ & $4.13 \pm 0.23 \mathrm{~B}$ & $4.53 \pm 0.61 \mathrm{C}$ \\
\hline \multicolumn{5}{|l|}{ Root length $(\mathrm{cm})$} \\
\hline ТPH-0 & $4.77 \pm 2.31 \mathrm{~A}$ & $25.88 \pm 0.98 \mathrm{~A}$ & $12.03 \pm 3.49 \mathrm{~A}$ & $14.30 \pm 4.85 \mathrm{~A}$ \\
\hline TPH-3 & $3.10 \pm 1.53 \mathrm{~A}$ & $17.96 \pm 2.31 \mathrm{~B}$ & $9.70 \pm 1.21 \mathrm{AB}$ & $8.93 \pm 1.27 \mathrm{AB}$ \\
\hline ТPH-6 & $2.07 \pm 2.30 \mathrm{~A}$ & $6.70 \pm 3.46 \mathrm{C}$ & $5.67 \pm 0.84 \mathrm{~B}$ & $5.70 \pm 0.55 \mathrm{~B}$ \\
\hline \multicolumn{5}{|l|}{ Root DW (g) } \\
\hline ТPH-0 & $0.26 \pm 0.13 \mathrm{~A}$ & $1.33 \pm 0.53 \mathrm{~A}$ & $0.95 \pm 0.52 \mathrm{~A}$ & $0.47 \pm 0.40 \mathrm{~A}$ \\
\hline ТPH-3 & $0.59 \pm 0.27 \mathrm{~A}$ & $1.07 \pm 0.15 \mathrm{~A}$ & $0.61 \pm 0.34 \mathrm{~A}$ & $0.20 \pm 0.15 \mathrm{~A}$ \\
\hline ТPH-6 & $0.41 \pm 0.53 \mathrm{~A}$ & $0.30 \pm 0.31 \mathrm{~B}$ & $0.92 \pm 0.07 \mathrm{~A}$ & $0.26 \pm 0.18 \mathrm{~A}$ \\
\hline \multicolumn{5}{|l|}{ Shoot DW $(g)$} \\
\hline TPH-0 & $2.78 \pm 0.87 \mathrm{~A}$ & $3.52 \pm 0.81 \mathrm{~A}$ & $2.73 \pm 0.42 \mathrm{~A}$ & $2.32 \pm 0.79 \mathrm{~A}$ \\
\hline ТPH-3 & $0.78 \pm 0.66 \mathrm{~B}$ & $1.02 \pm 0.45 \mathrm{~B}$ & $0.96 \pm 0.28 \mathrm{~B}$ & $0.20 \pm 0.09$ В \\
\hline ТPH-6 & $0.16 \pm 0.05 \mathrm{~B}$ & $0.61 \pm 0.27 \mathrm{~B}$ & $0.57 \pm 0.29 \mathrm{~B}$ & $0.04 \pm 0.02 \mathrm{~B}$ \\
\hline \multicolumn{5}{|l|}{ Root/shoot ratio } \\
\hline ТРН-0 & $0.09 \pm 0.04 \mathrm{~A}$ & $0.38 \pm 0.15 \mathrm{~A}$ & $0.35 \pm 0.40 \mathrm{~A}$ & $0.20 \pm 0.19 \mathrm{~B}$ \\
\hline ТРН-3 & $0.76 \pm 0.33 \mathrm{~A}$ & $1.05 \pm 0.34 \mathrm{~B}$ & $0.63 \pm 0.15 \mathrm{~B}$ & $1.00 \pm 0.10 \mathrm{~B}$ \\
\hline ТPH-6 & $2.56 \pm 0.12 \mathrm{~A}$ & $0.49 \pm 0.36 \mathrm{~B}$ & $1.61 \pm 0.27 \mathrm{~B}$ & $6.50 \pm 0.18 \mathrm{~A}$ \\
\hline \multicolumn{5}{|l|}{ Total DW (g) } \\
\hline TPH-0 & $3.03 \pm 1.00 \mathrm{~A}$ & $4.85 \pm 0.97 \mathrm{~A}$ & $3.68 \pm 0.68 \mathrm{~A}$ & $2.90 \pm 0.73 \mathrm{~A}$ \\
\hline ТPH-3 & $1.37 \pm 0.65 \mathrm{~B}$ & $2.08 \pm 0.46 \mathrm{~B}$ & $1.56 \pm 0.36 \mathrm{~B}$ & $0.33 \pm 0.13 \mathrm{~B}$ \\
\hline TPH-6 & $0.57 \pm 0.59 \mathrm{~B}$ & $0.91 \pm 0.30 \mathrm{~B}$ & $1.48 \pm 0.36 \mathrm{~B}$ & $0.26 \pm 0.16 \mathrm{~B}$ \\
\hline \multicolumn{5}{|l|}{$\begin{array}{l}\text { Stomatal density } \\
\left(\text { stomata/mm } / \mathrm{mm}^{2}\right)\end{array}$} \\
\hline ТРH-0 & $10.60 \pm 2.30 \mathrm{~B}$ & $4.33 \pm 0.57 \mathrm{~A}$ & $15.60 \pm 2.30 \mathrm{~A}$ & $25.60 \pm 9.29 \mathrm{~A}$ \\
\hline TPH-3 & $12.00 \pm 2.00 \mathrm{AB}$ & $5.00 \pm 1.73 \mathrm{~A}$ & $13.30 \pm 2.51 \mathrm{~A}$ & $23.00 \pm 1.00 \mathrm{~A}$ \\
\hline ТРН-6 & $15.30 \pm 0.57 \mathrm{~A}$ & $4.00 \pm 0.00 \mathrm{~A}$ & $11.60 \pm 2.51 \mathrm{~A}$ & $21.60 \pm 5.50 \mathrm{~A}$ \\
\hline
\end{tabular}

Significantly different for alphabetical code 

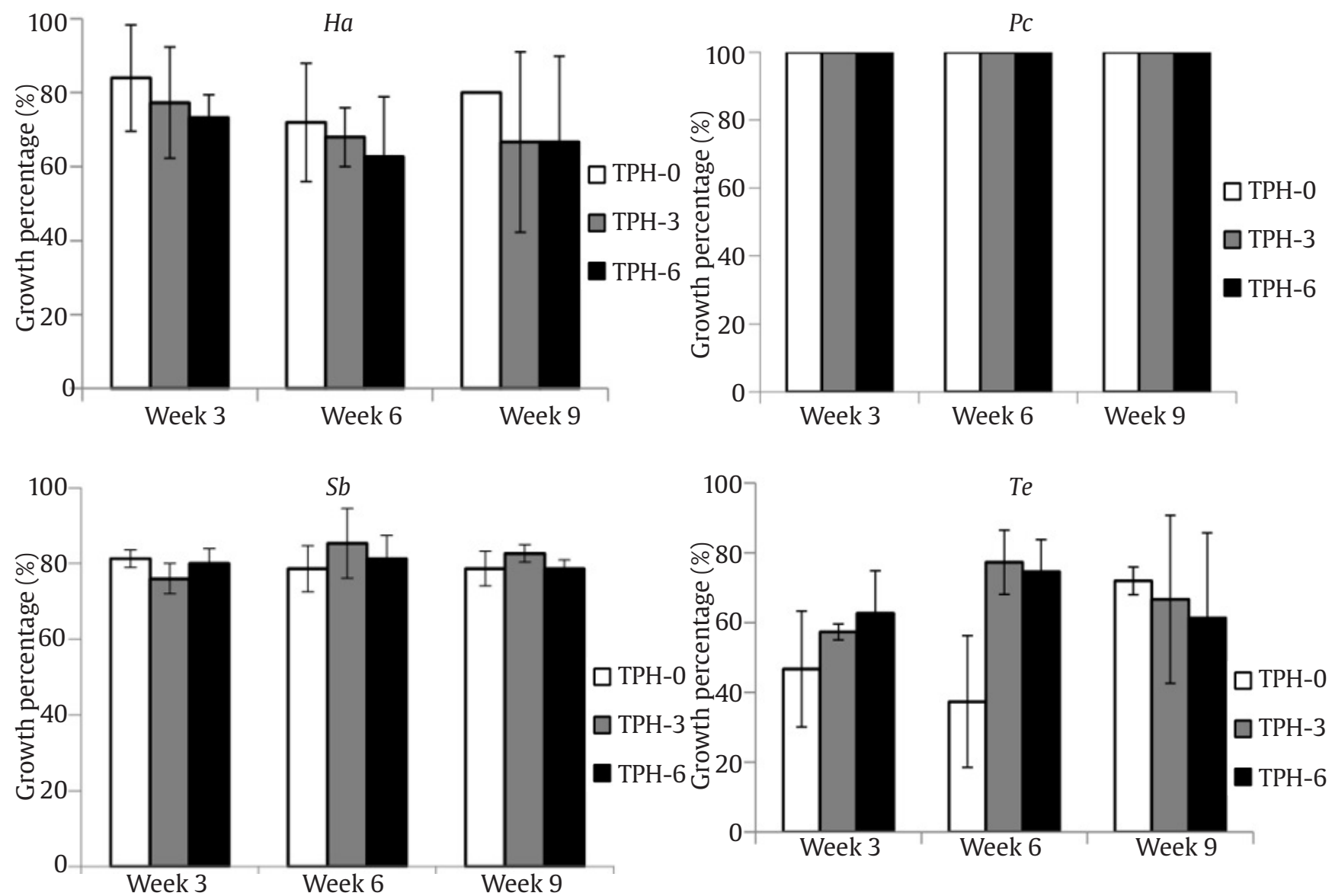

Figure 1. Growth percentage of $H$. annuus (Ha), P. conjugatum (Pc), S. bicolor (Sb), and T. erecta (Te) after 3 weeks, 6 weeks, and 9 weeks of planting

at TPH-0, TPH-3, and TPH-6 treatments. The better percentages after P. Conjugatum were S.bicolor (80\%), H. annuus (71\%), and lastly T. erecta (66\%).

Plant heights were affected by treatments. TPH0 (control) was the highest among other treatments (Figure 2). Treatments with the addition of crude oil of TPH-3 and TPH-6 were not significantly different, eventhough plant height of the four plants investigated at TPH-3 was higher than plant height in TPH-6. The concentration of crude oil increased, resulted in a decrease in plant height at week 3 , week 6 , and week 9 for all plants observed. Similar to plant height, number of leaves for each plant tended to decrease at higher TPH (Figure 3). Table 1 shows the higher of the concentration of crude oil in the soil, the less the root length of the four plants observed, eventhough there was no significant different for $H$. annuus.

The increasing in TPH level in soil caused the increasing in the root/shoot ratio for four plants observed (Figure 4), eventhough there was no significant different for $H$. annuus. Root DW of TPH treatment was not significantly different among treatments, except for TPH-3 and TPH-6 of $P$. conjugatum. There was a significantly different between TPH-3 and TPH-6 of P. conjugatum. The root DW and the shoot DW decreased with the increasing in TPH level (Table 1), and then the root/shoot ratio increase with the increasing in TPH level (Table 1 and Figure 4) for all plants. The root DW of $H$. annuus and $P$. conjugatum were higher at TPH-3 than at TPH-6 (Table 1). Root/shoot ratio of P. conjugatum at TPH-3 was higher than at TPH-6 (Figure 4).

Total DW of four plants investigated as a function of time and treatment (Figure 5). The number of leaves, root DW, shoot DW, and total DW of H. annuus tended to decrease with the increasing levels of $\mathrm{TPH}$, although it was not significantly different for leaf number, root length, and root DW. There was a significant different of total DW between control soil (TPH-0) and treated soil (TPH-3 and TPH-6). However, there was no significantly different of total DW between TPH-3 and TPH-6. 

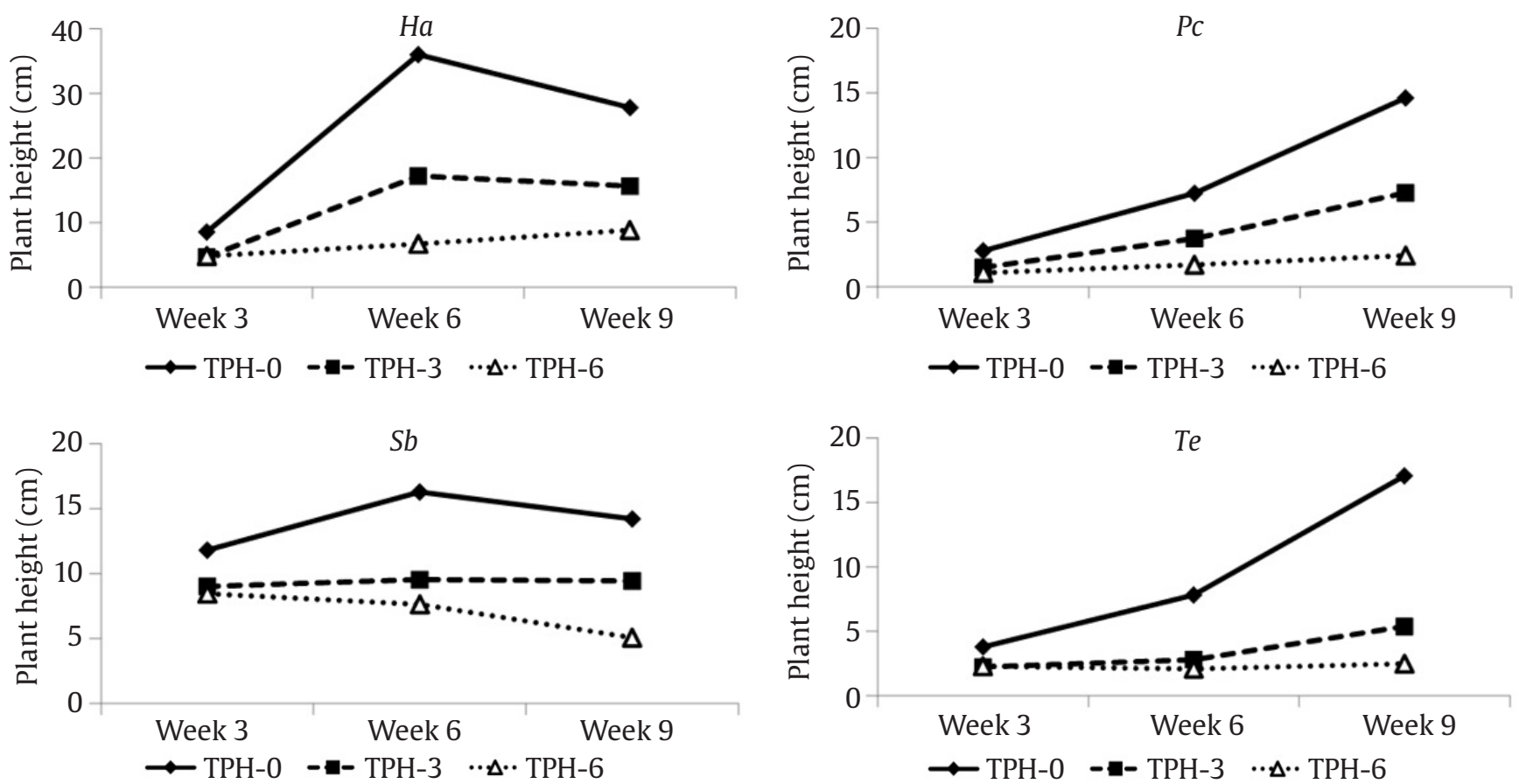

Figure 2. Plant height of H. annuus (Ha), P. conjugatum (Pc), S. bicolor (Sb), and T. erecta (Te) after 3 weeks, 6 weeks, and 9 weeks of planting
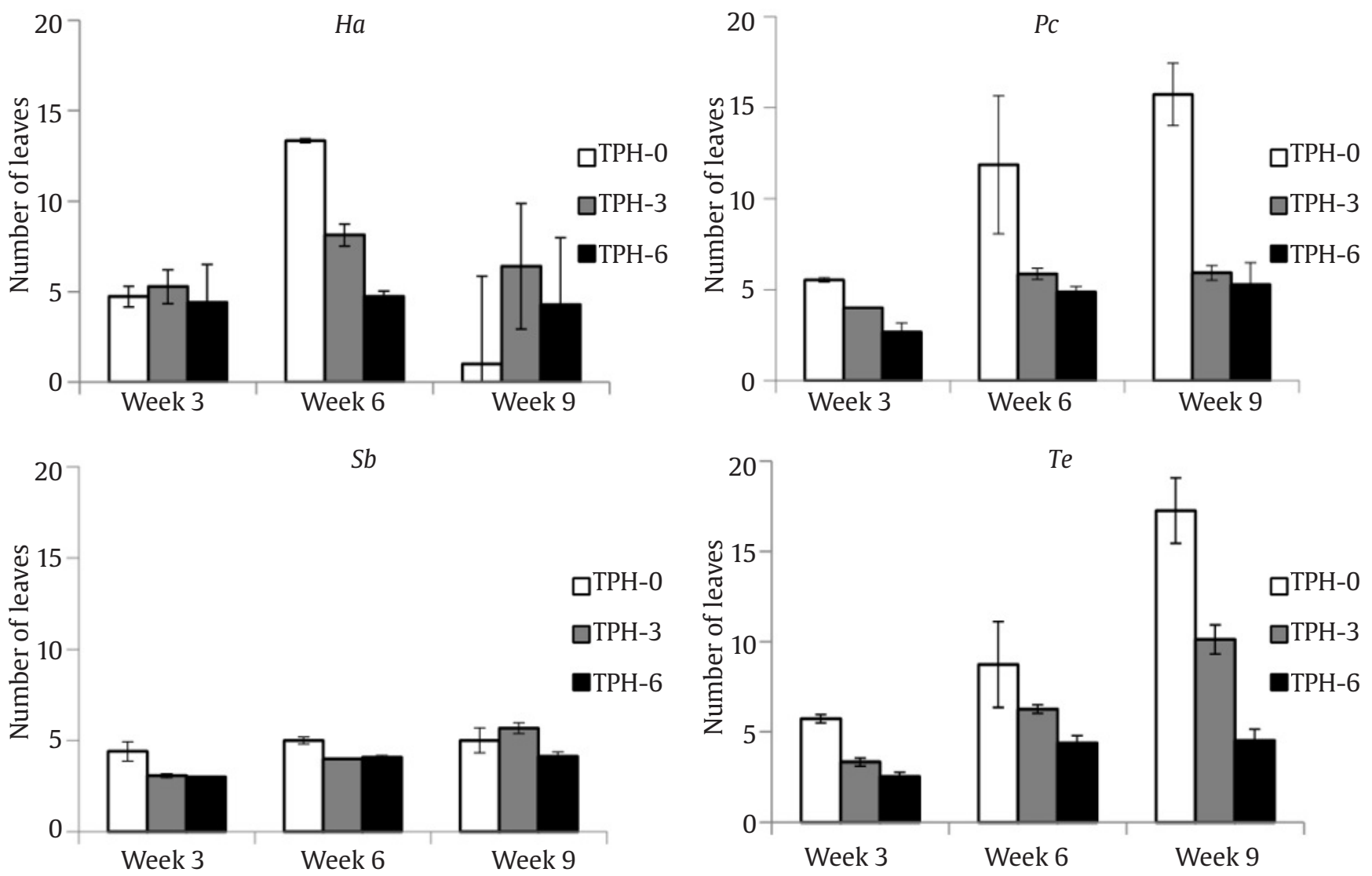

Figure 3. Number of leaves of H. annuus (Ha), P. conjugatum (Pc), S. bicolor (Sb), and T. erecta (Te) after 3 weeks, 6 weeks, and 9 weeks of planting 


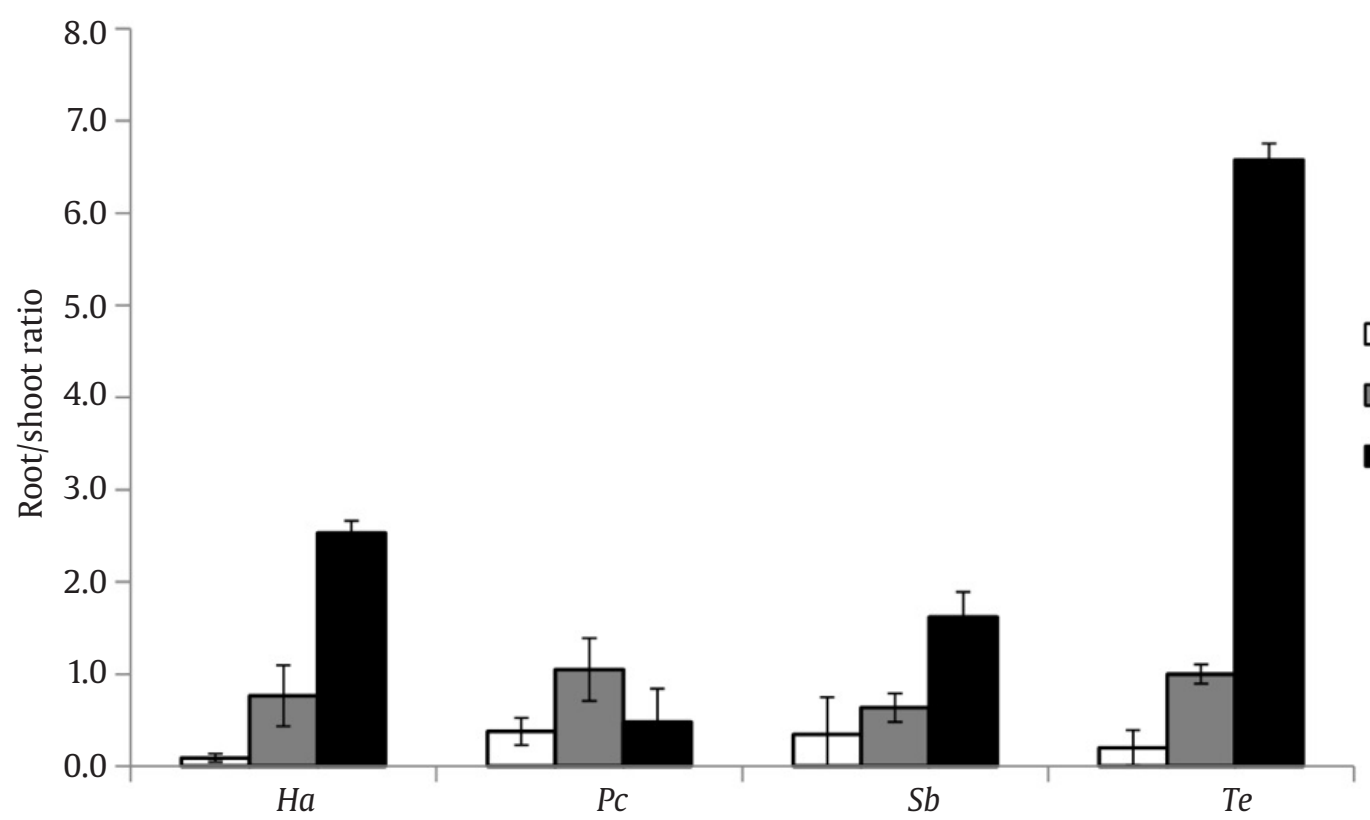

Figure 4. Root/shoot ratio of H. annuus (Ha), P. conjugatum (Pc), S. bicolor (Sb), and T. erecta (Te) after 9 weeks planting
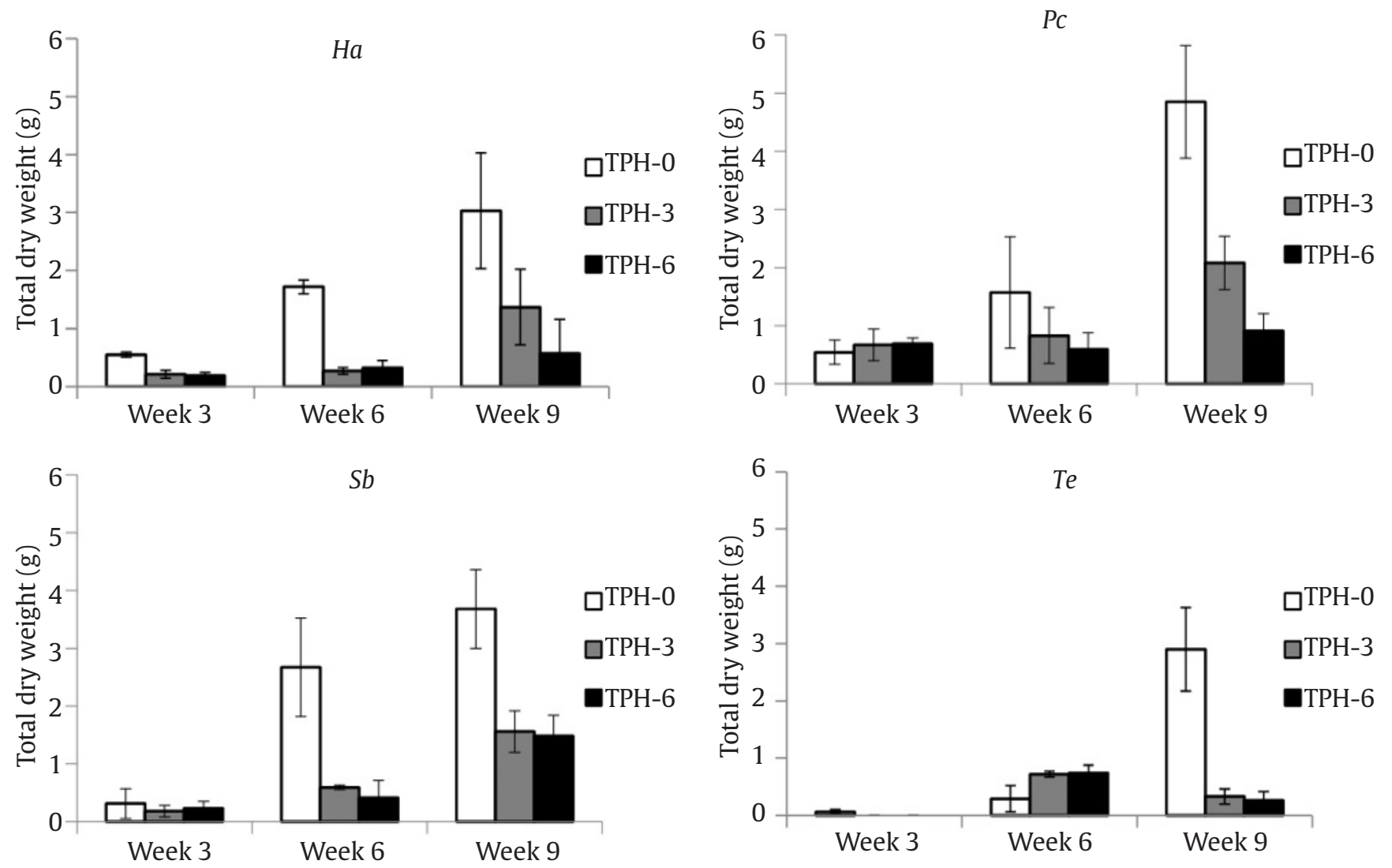

Figure 5. Total dry weight of H. annuus (Ha), P. conjugatum (Pc), S. bicolor (Sb), and T. erecta (Te) after 3 weeks, 6 weeks, and 9 weeks of planting 
The results of the morphological response of $P$. conjugatum showed that each parameter observed (plant height, number of leaves, root length, root DW, shoot DW, and total DW) decreased with increasing TPH. The parameters observed for S. bicolor decreased with increasing TPH levels, except for the number of leaves on TPH-3, which was higher than the control (Table 1). The T. erecta plant as well as the three plants described above decreased the parameters measured on the morphological aspects with increasing TPH (Table 1). Differences were observed among treatments, except root DW, which did not have a significantly different.

Stomatal density of $P$. conjugatum, S. bicolor, and $T$. erecta decreased with the increase of TPH level, however no significantly different was seen for stomatal density in 3 level of TPH. The lowest stomatal density occurred at TPH-6 in P. conjugatum, then S. bicolor, and T. erecta (Figure 6). In contrast, enhanced stomatal density was found in $H$. annuus with the increase of TPH.

Figure 7 shows cross sections of $S$. bicolor root at TPH-0, TPH-3, and TPH-6. At TPH-0, the epidermis was
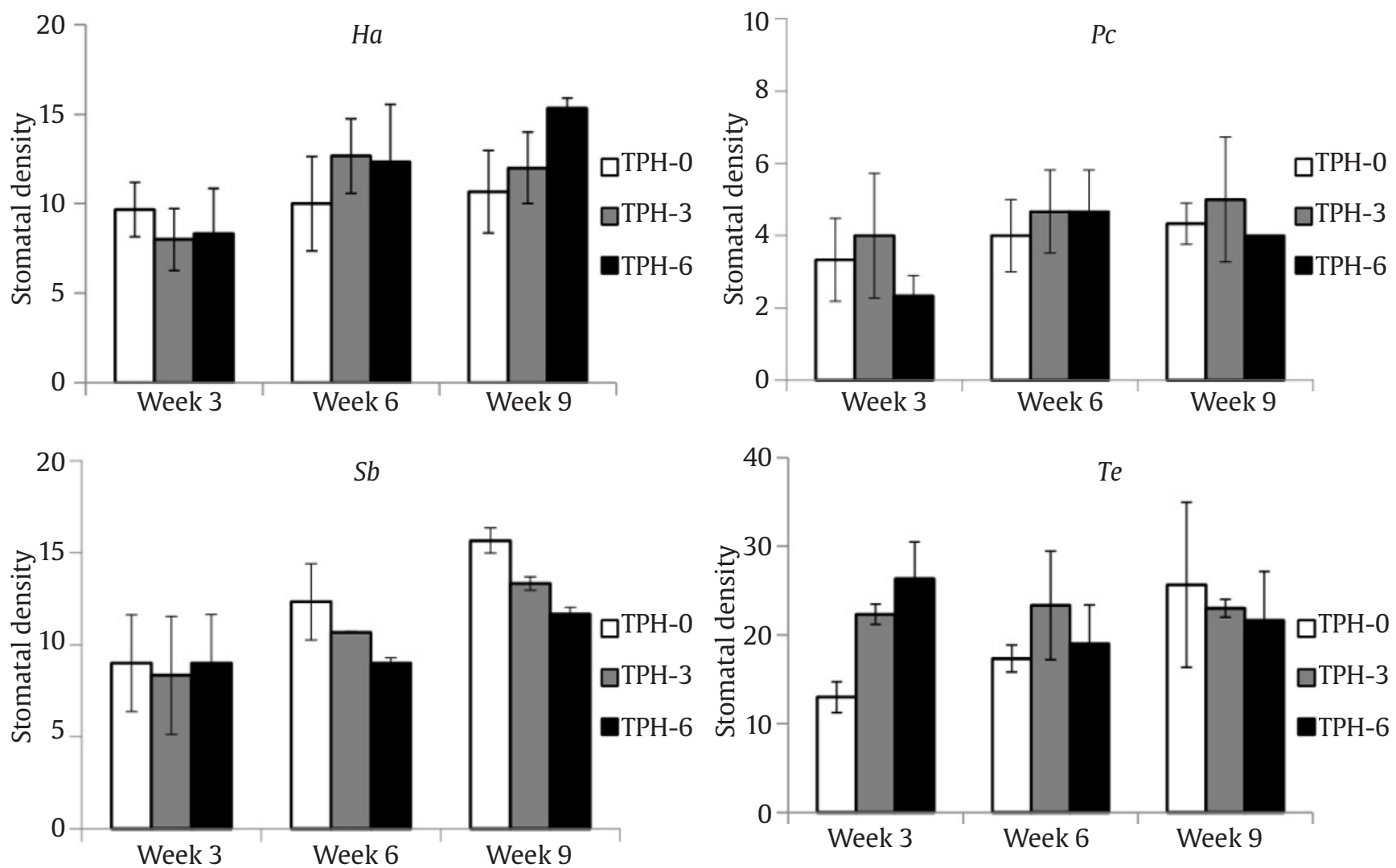

Figure 6. Stomatal density of H. annuus (Ha), P. conjugatum (Pc), S. bicolor (Sb), and T. erecta (Te) after 3 weeks, 6 weeks, and 9 weeks of planting

seen under normal condition. At TPH-3, the epidermis have been contaminated by petroleum entering the roots, some of the oil have reached the part of the cortex and endodermis. Oil quantity was seen more at TPH-6 treatment.

\subsection{Total Petroleum Hydrocarbon (TPH)}

TPH decline occurred significantly in all four types of plants used within 9 weeks. Figure 8 shows that the four selected plants were able to significantly reduce TPH (79.3-91.1\%) compared to TPH-0. The highest percentage decrease was achieved by P. conjugatum of $91 \%$ in TPH-3 and $90 \%$ in TPH-6. In the control treatment (without plant), there was also a 73\% TPH reduction at TPH-3 and $67 \%$ at TPH-6.

Based on the results mentioned above, it can be seen that the highest TPH reduction was $P$. conjugatum. Figure 8 shows that the concentrations of TPH- 3 and TPH-6 were not significantly different in all plants. However, the concentration of TPH-0 was significantly different from TPH-3 and TPH-6. 


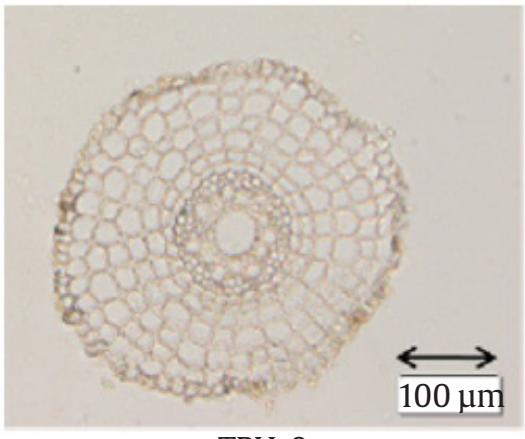

TPH-0
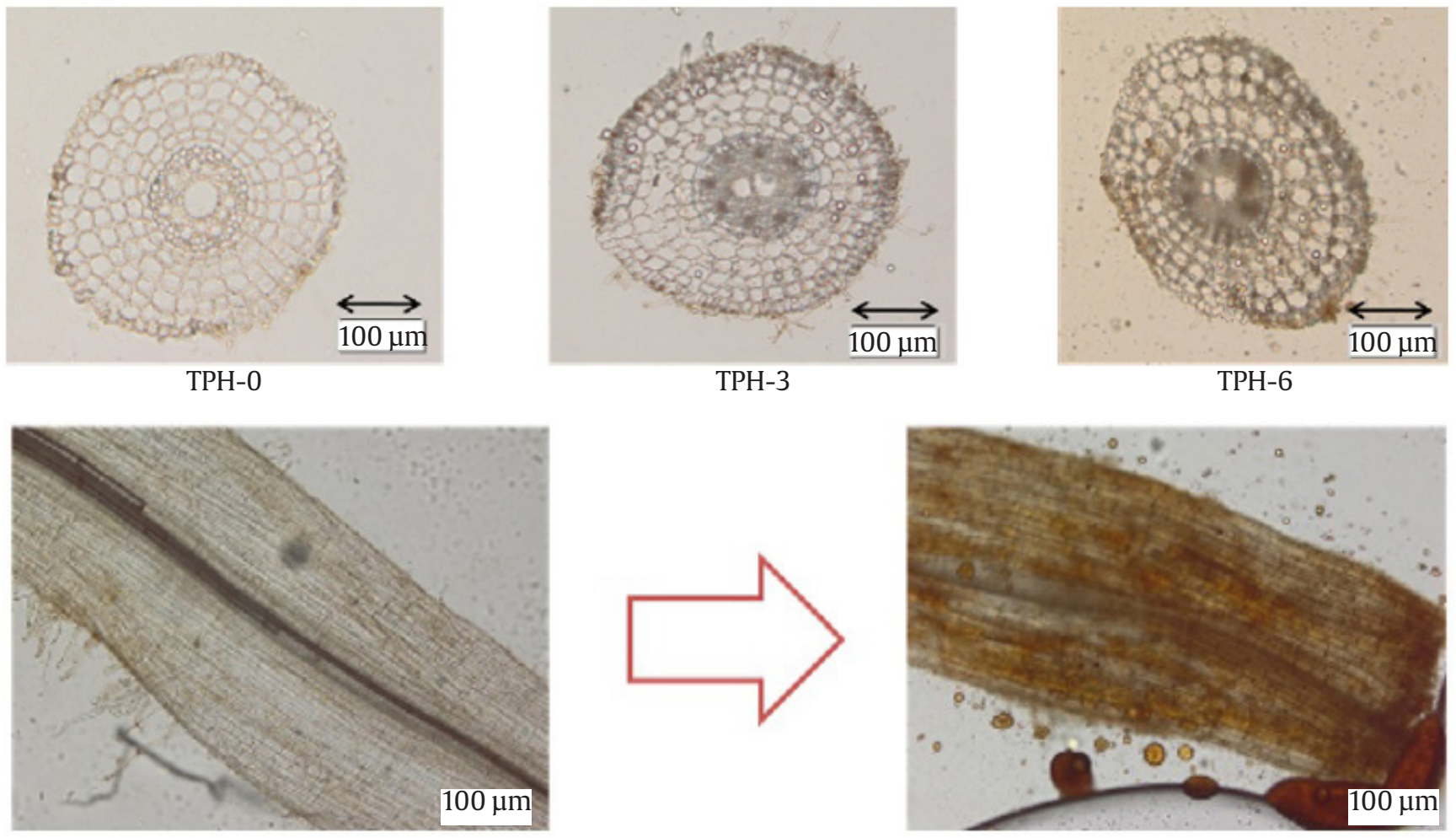

TPH-3

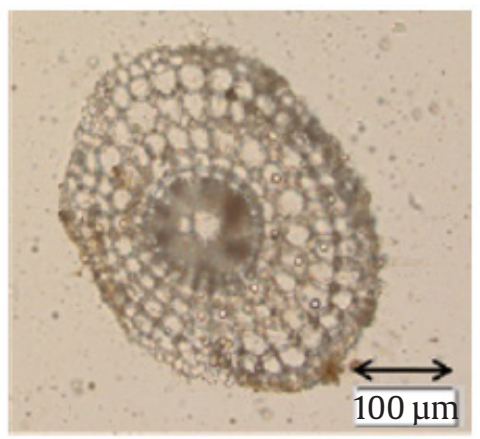

TPH-6

Figure 7. Section of S. bicolor root at TPH-0, TPH-3, and TPH-6 treatments(top). Root condition on TPH-0 and TPH-6 (below)

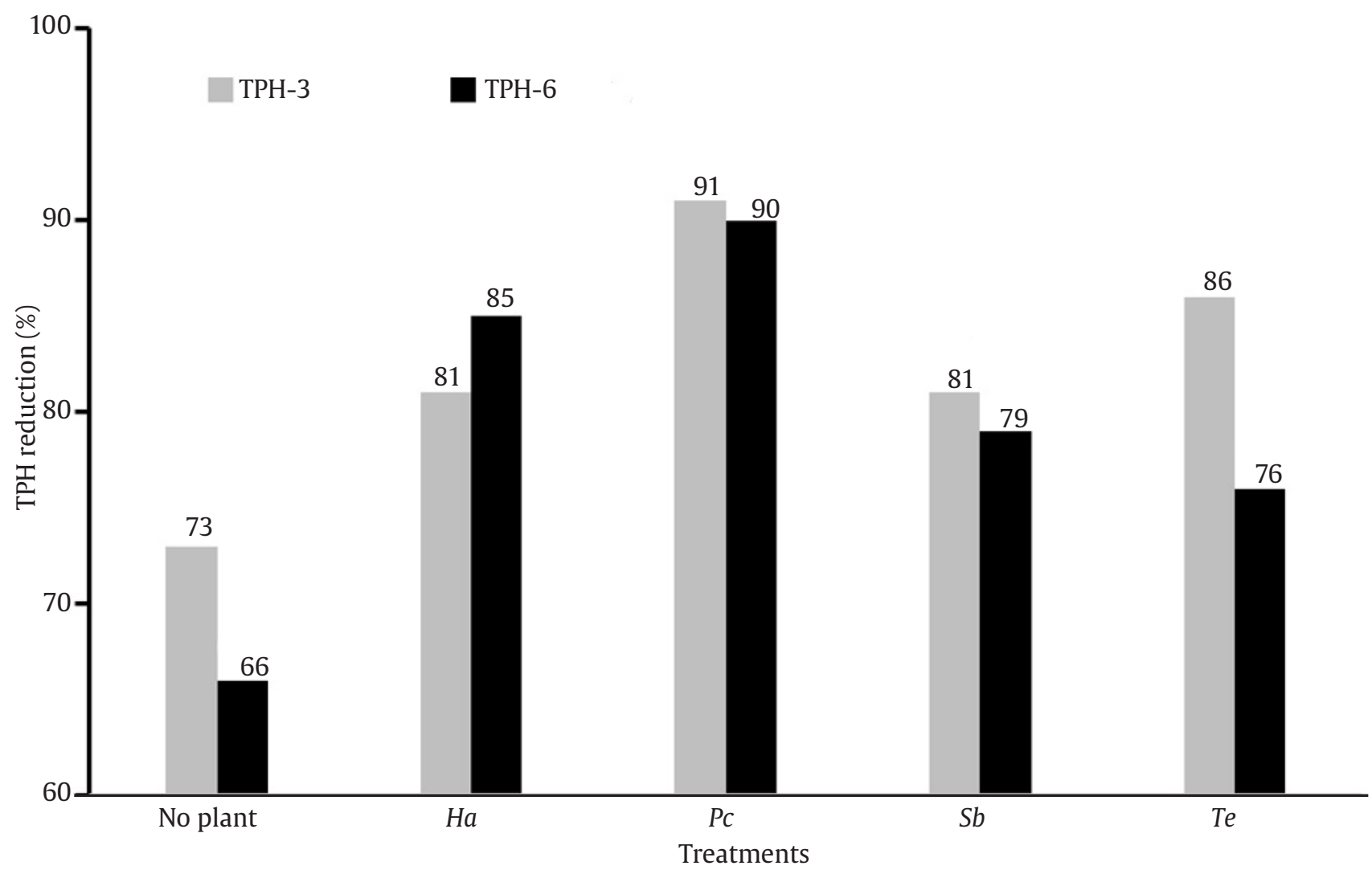

Figure 8. Percentage reduction of TPH in soil for control (no plant) and with H. annuus (Ha), P. conjugatum (Pc), S. bicolor $(\mathrm{Sb})$, and T. erecta $(\mathrm{Te})$ after 9 weeks planting 


\section{Discussion}

\subsection{Plant Morphological and Anatomical Responses}

Contamination of petroleum in soil have adverse effects to plant morphology and anatomy. Reduction in plant height are typical response caused by petroleum hydrocarbon contamination (Lin and Mendelssohn 1998; Ikhajiagbe and Anoliefo 2011). Amadi et al. (1996) reported that the presence of petroleum in soil caused the blocking of oxygen and water into the plant. The presence of crude oil in soil causes some harmful elements will be more available to the plant, so that plant growth is disrupted. Similar result was obtained by Basumatary and Bordoloi (2016) that Cynodon dactylon grown in petroleum contaminated soil had a plant height reduction. Inhibition of nutrients and water enter the plant, also caused the number of leaves produced by plants to decrease (Osuagwu et al. 2013). Okoloko and Berley (1982) also reported that petroleum contaminated soil causes disruption of membrane integrity and enzyme systems, thus ultimately disrupting the plant's metabolic system.

The decrease in root length was caused by osmotic stresses due to the increase of crude oil concentration, so that cell division at the root tip was inhibited. Some plants had the ability to increase the root area under hydrocarbon stress conditions by increasing the root length and multiplying the root branches to extend the root range to deeper soil layers, so that the root had a great opportunity to absorb more nutrition and water from soil.

The petroleum hydrocarbon stress condition triggered the plant to further increase root growth and suppressed the growth of the shoot so that the root/ shoot ratio became larger than the optimum condition (Table 1). The occurrence of the response is a form of plant adaptation to the conditions of petroleum hydrocarbon stress. By pushing the growth of the roots will provide a greater opportunity to absorb water by reaching a deeper layer of soil. Suppressing shoot growth reduces water loss (transpiration) through the leaves ( $\mathrm{Wu}$ and Cosgrove 2000).

The presence of petroleum hydrocarbons in soil inhibits photosynthesis, so carbon translocation is disturbed for shoot and root growth (Daly et al. 1988). Merkl et al. (2004) also reported that plant DW was significantly reduced in soil contaminated by petroleum hydrocarbons. Stress due to petroleum is analogous to the drought stress. Drought stress in some plants causes stomatal size and the number of stomata decrease (Price and Courtois 1991). They argued that the decrease of stomatal number is one of plant mechanisms to adapt to harsh environment by improving the balance and status of water. The status of plant water is useful for maintaining turgor and the entire biochemical process for plant activity and growth. Haryadi and Yahya (1988) also reported that reducing the amount of stomata is useful for reducing transpiration, so plants can maintain cell turgor, therefore plants can grow normally. $P$. conjugatum in this study had a low stomatal density as a form of adaptation to oil stress.

Unlike the three plants observed, stomatal density of $H$. annuus enhanced with the increase of TPH. Similar results obtained in Leymus chinensis (Zhenzhu and Guangsheng 2008). Zhang et al. (2006) also reported that stomatal density of Triticum aestivum also increased because of drought stress. Yin et al. (2006) argued that this phenomenon might not be associated with the plant response due to drought stress.

\subsection{Root Destruction}

Figure 7 clearly shows the negative effect of petroleum contaminated soil to the plant. At TPH-3, some of the crude oil have reached part of the cortex and endodermis of S. bicolor root, therefore it disturbed nutrition and water entering the roots. Figure 7 also shows that the oil particles were clearly more visible at TPH-6 compared to the control (TPH-0) and TPH-3 treatment. The crude oil might have damaged plant roots at TPH-6. The oil has reached cortex, endodermis, and stele (the central part of the root), which contains xylem and phloem. Petroleum might have translocated to the shoot, however the adaptation mechanism are not clearly understood.

\subsection{Total Petroleum Hydrocarbon (TPH) Degradation}

P. conjugatum and Tagetes erecta were usually used as phytoremediators for heavy metals polutant (Anoc and Rom 2000; Pas-Alberto et al. 2007; Ccoelho et al. 2017; Goswami and Das 2017). Little research in Indonesia was done to investigate potential plants for hydrocarbon phytoremediation. Setiadi et al. (2014) reported the use of four types of plants (P. conjugatum, Pueraria javanica, S. bicolor, and T. erecta) for adaptation in petroleum contaminated soil obtained from Sumatera island at TPH concentration of $0.43,1.41,4.69$, and $8.15 \%$ respectively. They concluded that grass type of plants (P. conjugatum and S. bicolor) had better growth potential compared to dicotyl species (P.javanica and $T$. 
erecta). Phytoremediation on petroleum contaminated soil using four types of grasses was also conducted by Salim and Suryati (2014) in Indonesia. After 12 months of planting, the four types of grass plants which were Eleusine indica, Paspalum notatum, Setaria splendida, and Stenotaphrum secundatum could play a role in the process of remediation of polluted soil containing 3.23\% TPH. The highest reduction percentage was obtained from Paspalum notatum (38.81\%), followed by Eleusine indica (38.69\%), Setaria splendida (36.34\%), and Stenotaphrum secundatum (29.32\%). Ervayenri (2015) used Ficus sp. seedlings for his phytoremediation study and found out that Ficus sp. was not able to survive more than $5 \% \mathrm{TPH}$ without inoculation by arbuscular mycorrhizal fungi (AMF).

The results of this research showed that $P$. conjugatum and S. bicolor were most resistant to crude oil at TPH3 and TPH-6 levels compared to the other two plants (Helianthus annuus and Tagetes erecta) although not significantly different. This is consistent with the opinion of April and Sims (1990) that grasses have enormous potential compared to other plants as phytoremediators, because grasses have a strong root system and good roots distribution in soil. The fibrous and highly branched grass root systems allow large volumes of soil to be explored for nutrient uptake and transport (Siddiqui et al. 2001; Merckl et al. 2005). Merkl et al. (2005) showed enhanced degradation of petroleum hydrocarbon using tropical grasses and legumes after a few months. Removal of 30\% TPH was reported by Huang et al. (2005) in Festuca arundinaceae in 120 days. Razmjoo and Adavi (2011) found out that there was $40 \%$ TPH reduction by Cynodon dactylon in 6 months.

Phytoremediation of contaminated soil of petroleum hydrocarbons is dependent on highly tolerant and growing plant species in locations in the presence of peroleum (Hernández-Ortega et al. 2012). Plants on contaminated soil also allow the biological transformation of organic contaminants by stimulating microbial activity through root exudates. The root exudates acts as a source of nutrients for microbes degrading organic pollutants (Anderson et al. 1993). In addition, root exudates are also co-substrate for microbes. Roots can alter the soil porosity, so it may help the microbe in degrading petroleum hydrocarbons in soil (Yan-zheng and Li-zhong 2003).

Plants can remove toxic effects of contaminants in petroleum contaminated soil, because plants can adapt by certain physiological responses, such as improvement in nutient and water uptake and free-radical scavenging systems induction to prevent cell distruction (Misra and Gupta 2006). The occurrence of stress in plants causes a decrease in leaf osmotic potential followed by accumulation of proline (Sopandie et al. 1996). Hydrocarbon exposure also cause oxidative stress, which is indicated by over-expression of superoxide dismutase (SOD) (Gupta et al. 1993).

The function of plant roots is not only in absorbing nutrients and water in the soil, but also in overcoming the presence of contaminants in the soil. Mutualism symbiosis between microbes and plants by recycling, solubilization, and supplying vitamins, amino acids, and plant hormones by microbes, stimulates the plant growth (Escalante-Espinosa et al. 2005). In this study, a higher degradation of TPH in soil vegetated with the four types of plants used compared to unvegetated soil. However, there was a TPH redution at TPH-3 (73\%) and at TPH-6 (67\%) for the treatment without plant. This might be due to microclimate changes, such as temperature, light, dissolving to water, and composting.

\section{Conclusion}

According to the ability in decreasing the TPH, it can be concluded that all four types of plants that were selected could grow under TPH-3 and TPH6 conditions. It means that the four types of plants are potential as phytoremediators, eventhough in this study, there was a TPH reduction at TPH-3 and TPH-6 at the treatment without plant. Selected grass species studied could be used for phytoremediation of petroleum hydrocarbon contaminants in soil due to their adaptability. $P$. conjugatum and $S$. bicolor are recommended for future experiments based on their growth rate and great tolerance to petroleum hydrocarbon. This is one of the first studies explaining the success of utilizing $P$. conjugatum and T. erecta for phytoremediation of soil contaminated by crude oil.

\section{Acknowledgements}

Authors would like to acknowledge the Lab of Forest Biotechnology Laboratory-Biotechnology Resource Research Center and the Microtechnique Laboratory-IPB University and the Lab of Analytics, the Institute of Environmental Technology-BPPT for providing technical support for laboratory work. Special thanks are also conveyed to the screenhouse staffs for providing support for screenhouse work. 


\section{References}

Amadi A et al. 1996. Chronic effect of oil spill on soil properties and microflora of a rainforest ecosystem in Nigeria. Water Air Soil Pollut 96:1-11.

Anderson TA et al. 1993. Bioremediation in the rhizosphereplant roots and associated microbes clean contaminated soils. Environ Sci Technol 27:2630-2636.

Anoc LF, Rom SQ. 2000. Phytoremediation potential of Bermuda grass (Cynodon dactylon) and Carabao grass (Paspalum conjugatum) in lead deposition: a comparative study. Int J Phytorem 2:297-317.

April W, Sims RC. 1990. Evaluation of the use of prairie grasses for stimulating polycyclic aromatic hydrocarbon treatment in soil. Chemosphere 20:253-265.

Basumatary B, Bordoloi S. 2016. Phytoremediation of crude oil-contaminated soil using Cynodon dactylon (L.) Pers. In: Ansari AA, Gill SS, Gill R, Lanza GR, Newman L (Eds.).Phytoremediation Management of Environmental Contaminants. Switzerland: Springer. pp. 41-51.

Biswas K et al. 2015. Biological agents of bioremediation: a concise review. Frontiers in Environ Microbiol 1:39-43.

Ccoelho Let al. 2007. Marigold (Tagetes erecta): The potential value in the phytoremediation of chromium. Pedosphere 27:559-568.

Daly EJ et al. 1988. The effects of oil spill chemicals on carbon translocation rates in Phaseolus vulgaris L. Environ Pollut 52:151-163.

Eapen S, D'Souza SF. 2005. Prospects of genetic engineering of plants for phytoremediation of toxic metals. Biotechnol Adv 23:97-114.

Ervayenri. 2005. Pemanfaatan fungi mikoriza arbuskula (FMA) dan tanaman indigenous untuk revegetasi lahan tercemar minyak bumi [Disertasi]. Indonesia, Bogor: Institut Pertanian Bogor.

Escalante-Espinosa et al. 2005. Improvement of the hydrocarbon phytoremediation rate by Cyperus laxus Lam. inoculated witha microbial consortium in a model system. Chemosphere 59:405-413.

Euliss $\mathrm{K}$ et al. 2008. Greenhouse and field assessment of phytoremediation for petroleum contaminants in a riparian zone. Bioresour Technol 99:1961-1971.

Gerhardt KEetal.2009.Phytoremediation and rhizoremediation of organic soil contaminants: potential and challenges. Plant Sci 176:20-30.

GlickBR. 2010. Using soil bacteria to facilitate phytoremediation. Biotechnol Adv 28:367-374.

Gomez KA, Gomez AA. 1984. Statistical Procedures for Agricultural Research. $2^{\text {nd }}$ Ed. New York: J Wiley.

Goswami S, Das S. 2017. Screening of cadmium and copper phytoremediation ability of Tagetes erecta, using biochemical parameters and scanning electron microscopy-energy-dispersive X-ray microanalysis. Environ Toxicol Chem 36:2533-2542.

Gupta AS et al. 1993. Overexpression of superoxide dismutase protects plants from oxidative stress. Plant Physiol 103:1067-1073.

Haryadi SS, Yahya S. 1988. Fisiologi Stres Lingkungan. Bogor: PAU Biotek IPB.

Hernandez-Ortetga HA et al. 2012. Arbuscular mycorrhizal fungi on growth, nutrient status, and total antioxidant activity of Melilotus albus during phytoremediation of a diesel-contaminated substrate.J Environ Manage 95:319-324.
Huang X et al. 2005. A multi-process phytoremediation system for decotamination of persistent total petroleum hydrocarbons (TPHs) from soils. Microchem J 81:139147.

Ikhajiagbe B, Anoliefo GO. 2011. Natural attenuation of a 14-month-old waste engine oil polluted soil. J SSEM 2:184-192.

Jones $\mathrm{R}$ et al. 2004. Phytoremediation of petroleum hydrocarbons in tropical coastal soils. II. Microbial response to plant roots and contaminant. Environ Sci Pollut Res 11:340-346.

Kaimi E et al. 2006. Ryegrass enhancement of biodegredation in diesel-contaminated soil. Environ Exp Bot 55:110-119.

[Kemenhut] Kementerian Kehutanan. 2011.Peraturan Menteri Kehutanan Republik Indonesia Nomor 18 Tahun 2011 tentang Pedoman Pinjam Pakai Kawasan Hutan.Jakarta: Kemenhut.

Kirkpatrick WD et al. 2006. Selecting plants and nitrogen rates to vegetate crude-oil contaminates soil. Int J Phytoremed 8:285-297.

Lalande T et al. 2003. Phytoremediation of pyrene in a cecil soil under fieldconditions. Int J Phytoremed 5:1-12.

Linn Q Mendelssohn IA. 1998. The combined effects of phytoremediation and biostimulation in enhancing habitat restoration and oil degradation of petroleum contaminated wetlands. Ecol Eng 10:263-274.

Macek T et al. 2000. Exploitation of plants for the removal of organics in environmental remediation. Biotechnol Adv 18:23-34.

Merkl N et al. 2004. Phytoremediation in the tropics-the effect of crude oil on the growth of tropical plants. Biorem J 8:177-184.

Merkl N et al. 2005. Assessment of tropical grasses and legumes for phytoremediation of petroleum-contaminated soils. Water Air Soil Pollut 165:195-209.

Misra N, Gupta AK. 2006. Effect of salinity and differential nitrogen sources on the activity of antioxidant enzymes and indole alkaloid content in Catharenthus roseus seedlings. J Plant Physiol163:11-18.

Okoloko GE, Berley JD. 1982. SO2-induced changed in the polyribosomal profiles of the gametophyte of the moss Tortula ruralis. Plant cell Rep 2:63-65.

Osuagwu AN et al. 2013. Effect of crude oil pollution on growth parameters, chlorophyll content and Bulbils yield in air potato (Dioscorea bulbifera L.). Int J Applied Sci and Technol 3:37-42.

Paz-Alberto AM et al. 2007. Phytoextraction of leadcontaminated soil using vetivergrass (Vetiveria zizanioides L.), cogongrass (Imperata cylindrica L.) and carabaograss (Paspalum conjugatum L.). Environ Sci Pollut Res Int 14:498-504.

Peng S et al. 2009. Phytoremediation of petroleum contaminated soils by Mirabilis jalapa L in a greenhouse plot experiment. J Hazard Mater 168:1490-1496.

Pilon-Smits E. 2005. Phytoremediation. Annual Rev Plant Biol 56:15-39.

Price A, Courtois B. 1991. Mapping QTLs Associated with Drought Resistance in Rice: Progress Problem and Prospect. Los Banos: Int Rice Res Inst.

Razmjoo K, Adavi Z. 2011. Assessment of bermuda grass cultivars for phytoremediation of petroleum contaminated soils. Int J Phytoremed 14:14-23. 
Salim F, Suryati T. 2014. Fitoremediasi tanah tercemar minyak bumi menggunakan empat jenis rumput.JRiset Industri 8:123-128.

Setiadi Y et al. 1992. Mikrobiologi Tanah Hutan. Bogor: PAU Bioteknologi Tanaman Pangan, IPB.

Setiadi Y. 2012. Pembenahan lahan pasca tambang. Post Mining Restoration Technical Note. Tidak dipublikasikan.

Setiadi Y et al. 2014. Seleksi adaptasi jenis tanaman pada tanah tercemar minyak bumi. J Silv Trop 5:160-166.

Siddiqui S et al. 2001. The phytotoxicity and degradation of diesel hydrocarbons in soil. J Plant Nutr Soil Sci 164:631-635.

Singh OV, Jain RK. 2003. Phytoremediation of toxic aromatic pollutants from soil. Appl Microbiol Biotechnol 63:128135.

Sopandie D et al. 1996. Toleransi kedelai terhadap cekaman kekeringan: akumulasi prolin dan asam absisik dan hubungannya dengan potensial osmotik daun dan penyesuaian osmotik. Bul Agron 24:9-14.

[USEPA] United States Environmental Protection Agency. 1996. Soxhlet Extraction, partof Test Methods for Evaluating Solid Waste. Washington DC: USEPA.
Wu Y, Cosgrove DJ. 2000. Adaptation of root tolow water potentials by changes in cell wall extensibility and cell wall proteins. J Exper Bot 51:1543-1553.

Yan-zheng G, Li-zhong Z. 2003. Phytoremediation and its models for organic contaminated soils. J Environ Sci 5:302-310.

Yani M et al. 2003. Bioremediasi lahan terkontaminasi senyawa hidrokarbon. In: Prosiding Seminar Bioremediasi dan Rehabilitasi Lahan Sekitar Perminyakan dan Pertambangan. Bogor: Forum Bioremediasi IPB. pp. 15-30.

Yin X et al. 2006. Study on the stomatal density and daily change rule of the wheat. Chinese Agric Sci Bull 22:237242.

Zhang YP et al. 2006. Stomatal characteristics of different green organs in wheat under different irrigation regimes. Acta Agron Sin 32:70-75.

Zhenzhu X, Guangsheng Z. 2008. Responses of leaf stomatal density to water status and its relationship with photosynthesis in a grass. J Exp Bot 59:3317-3325. 